\title{
The complete genome sequence of the archaeal isolate Halomicrobium sp. ZPS1 reveals the nitrogen metabolism characteristics under hypersaline conditions
}

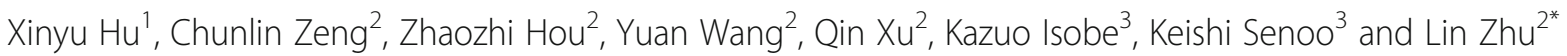

\begin{abstract}
Purpose: As a potential tool for the biodegradation of nitrogen contaminants, including nitrate, nitrite, and ammonium, in pickled foods with high salinity, the halophilic and denitrifying archaeal strain Halomicrobium sp. ZPS1 was isolated from edible salt particles.

Methods: Under anaerobic and static culture conditions, Halomicrobium sp. ZPS1 could simultaneously degrade nitrate, nitrite, and ammonium in liquid medium with $18 \%$ salinity and generate $\mathrm{N}_{2} \mathrm{O}$. To gain insight into these physiological characteristics, the complete genome of Halomicrobium sp. ZPS1 was sequenced to reveal the mechanism of nitrogen metabolism associated with salt-tolerance.

Result: The complete genome sequencing revealed a genome size of 3,094,203 bp with a circular chromosome and a GC content of 65.64\%. Based on gene annotation, 3191 CDSs, 6 rRNA genes, and 76 tRNA genes were identified. Moreover, 28 genes were annotated as related to salt tolerance, ammonium assimilation, and a truncated denitrification pathway.

Conclusion: The annotated functional genes indicate that Halomicrobium sp. ZPS1 could be a candidate strain for the simultaneous removal of nitrate, nitrite, and ammonia in extremely high salt environments.
\end{abstract}

Keywords: Halomicrobium sp., Salt tolerance, Ammonia assimilation, Denitrification

\section{Introduction}

Various vegetables, which contain an abundance of nitrate and ammonium resulting from excessive nitrogen fertilization, can be pickled into various table food in China and other Asian countries. The nitrate contained in plant tissues can be reduced to nitrite, which causes anoxia poisoning and cancer (Zhong et al. 2002). Ammonium contained in plant tissues is also harmful to human health (Yusof et al. 2010). Therefore, the removal of excessive nitrate, nitrite, and ammonium is critical for the production of salted vegetables. Spoilage bacteria

\footnotetext{
* Correspondence: 1000004488@ujs.edu.cn

${ }^{2}$ School of Food and Biological Engineering, Jiangsu University, Zhenjiang, China

Full list of author information is available at the end of the article
}

have been considered to reduce nitrate to nitrite in pickled vegetables, and lactic acid bacteria are considered to be powerful microbial barriers to the degradation of nitrite in pickled vegetables (Oh et al. 2004; Yan et al. 2008). For the removal of ammonium, some bacteria belonging to Planctomycetes are considered to completely oxidize ammonium to produce nitrogen through Anammox processes (Jetten et al. 2001). However, the high salinity in salted vegetables inhibits the normal growth and metabolism of these microorganisms (Carr et al. 2002) and limits their capability of removing nitrogen contaminants.

Haloarchaea, a group of halophilic archaea, could thrive in hypersaline environments from $1 \mathrm{M}$ to $5.3 \mathrm{M}$ $\mathrm{NaCl}$ (Aharon 2002; Pfeifer 2015), and it is widely

(c) The Author(s). 2020 Open Access This article is licensed under a Creative Commons Attribution 4.0 International License, which permits use, sharing, adaptation, distribution and reproduction in any medium or format, as long as you give appropriate credit to the original author(s) and the source, provide a link to the Creative Commons licence, and indicate if changes were made. The images or other third party material in this article are included in the article's Creative Commons licence, unless indicated otherwise in a credit line to the material. If material is not included in the article's Creative Commons licence and your intended use is not permitted by statutory regulation or exceeds the permitted use, you will need to obtain permission directly from the copyright holder. To view a copy of this licence, visit http://creativecommons.org/licenses/by/4.0/. 
distributed on edible salt particles (Henriet et al. 2014). It has been reported that some haloarchaea, such as Haloferax mediterranei (Cheung et al. 1997), Haloferax volcanii and Haloferax denitrificans (Torregrosa-Crespo et al. 2019), and Haloarcula marismortui (Yoshimatsu et al. 2000), possesses denitrification genes and could perform denitrification or truncated denitrification pathways. Simultaneously, we found that haloarchaea can grow in medium with ammonium as the only nitrogen source (data not shown). Thus, we considered that haloarchaea could be a candidate microorganism for the simultaneous removal of nitrate, nitrite, and ammonia through assimilated and dissimilated nitrogen metabolism in a hypersaline environment. Here, the archaeal strain Halomicrobium sp. ZPS1 was isolated from edible salt particles produced in the Zhangpu Salt Field of China and was shown to be capable of degrading nitrate, nitrite, and ammonium under high salinity conditions. We describe the complete genome of Halomicrobium sp. ZPS1 to gain insight into the mechanism of nitrogen metabolism in extreme salt environments. The result may improve the theoretical basis and practical applications of haloarchaea in the removal of nitrogen during salted vegetable production, as well as other high salinity environments.

\section{Materials and methods}

\section{The removal capability of nitrogen contaminants}

Halomicrobium sp. ZPS1 was cultivated in HNM medium for $96 \mathrm{~h}$, and $1 \mathrm{ml}$ of culture was transferred to vials containing modified HNM medium, which contained 18\% (w/v) $\mathrm{NaCl}$ and $\mathrm{NaNO}_{3}, \mathrm{NaNO}_{2}$, and $\mathrm{NH}_{4} \mathrm{Cl}$ at a final concentration of $1 \mathrm{mM}$. The final $\mathrm{pH}$ was 7.0. After replacing the air with Ar, the vials were sealed with rubber septa and aluminum cap (Torregrosa-Crespo et al. 2019). During an observation period of $84 \mathrm{~h}$, liquid and gas samples were collected every $12 \mathrm{~h}$ to determine the concentrations of nitrate, nitrite, ammonium, $\mathrm{N}_{2} \mathrm{O}$, and $\mathrm{N}_{2}$. The concentration of nitrate and nitrite was measured by using cadmium column reduction and the $N$-(1-naphthyl)-ethylenediamine dihydrochloride spectrophotometric method (Ozdestan and Uren 2010; Ding et al. 2018). The concentration of ammonium was determined by the phenol-hypochlorous acid method (Ngo et al. 1982). Gas components were detected by gas chromatography with a TCD and ECD detector (SHIMADZU-2014).

\section{Sample preparation and genome DNA extraction}

The strain Halomicrobium sp. ZPS1 was cultured in NOM liquid medium at $37{ }^{\circ} \mathrm{C}$ and enriched to the midlogarithmic phase. We used the SDS method to extract the genomic DNA of Halomicrobium sp. ZPS1 and determined the quality and quantity of the DNA by agarose gel electrophoresis and Qubit 2.0, respectively.

\section{Genome sequencing and assembly}

The genome of Halomicrobium sp. ZPS1 was sent to Beijing Novogene Bioinformatics Technology Co., Ltd., and sequenced by Pacific Biosciences RS II single-molecule realtime (SMRT) sequencing technology and high throughput Illumina sequencing technology (Mardis 2017; Hebert et al. 2018). We obtained low-quality reads after filtering raw data from the PacBio RS II and Illumina PE150 sequencer, and the reads were filtered by SMRT Link 5.0.1 (https://www. pacb.com/support/software-downloads/) (Ardui et al. 2018; Reiner et al. 2018) to generate contigs.

\section{Analysis of genome composition}

We used GeneMarkS4.17 (Besemer et al. 2001) to predict protein-encoding genes, RNAmmer (Lagesen et al. 2007) to predict ribosomal RNA (rRNA) genes, tRNAscan-SE 1.3.1(Lowe and Eddy 1997) to predict transfer RNA (tRNA) genes, and BLAST in the Rfam database to predict small nuclear RNAs (snRNA) (Gardner et al. 2008). The Genomics Islands were predicted through the IslandPathDIOMB program (Hsiao et al. 2003), and the transposons were predicted through transposon PSI (http://transposonpsi.sourceforge.net/). PHAST (Zhou et al. 2011) was used for prophage prediction, and CRISPRFinder (Grissa et al. 2007) was used for CRISPR identification. The interspersed repetitive sequences were predicted through TRF (Tandem Repeats Finder, Version 4.07b) (Benson 1999).

\section{Genome annotation}

Five databases were used to predict gene functions: GO (Gene Ontology) (Ashburner et al. 2000), KEGG (Kyoto Encyclopedia of Genes and Genomes) (Kanehisa et al. 2004; Kanehisa et al. 2006), COG (Clusters of Orthologous Groups) (Galperin et al. 2014), NR (Non-Redundant Protein Database databases) (Li et al. 2002), and CAZy (Carbohydrate-Active enzyme database) (Cantarel et al. 2008). A whole-genome blast search, which had an $E$ value of less than $1 \mathrm{e}-5$ and a minimal alignment length percentage larger than $40 \%$, was performed against above the five databases. In addition, we used Mega7.0, and DNAMAN software to analyze sequences of $16 \mathrm{~S}$ rRNA and enzymes.

\section{The assessment of potential secondary metabolites}

To assess the potential secondary metabolites of Halomicrobium sp. ZPS1, we used antiSMASH (Medema et al. 2011) to predict the number of biosynthetic gene clusters (BGCs).

\section{Data deposition}

The complete genome sequence of Halomicrobium sp. ZPS1 has been deposited in GenBank under the accession number CP045142. 


\section{Results}

Nitrogen metabolism pathway of Halomicrobium sp. ZPS1 under high salinity conditions

Under the condition of $18 \%$ salt concentration, the degradation rate of $\mathrm{NO}_{3}{ }^{-}$in the medium reached $95.1 \%$ in $60 \mathrm{~h}$, and the degradation rate of $\mathrm{NO}_{2}{ }^{-}$reached $98.3 \%$ in $84 \mathrm{~h}$ after fluctuating. $\mathrm{NH}_{4}{ }^{+}$continued to decline, and the degradation rate reached $52.2 \%$ at $84 \mathrm{~h}$. Gas detection results showed that a large amount of $\mathrm{N}_{2} \mathrm{O}$ was generated without $\mathrm{N}_{2}$ production. These results suggest that the strain Halomicrobium sp. ZPS1 has the ability to simultaneously metabolize $\mathrm{NO}_{3}{ }^{-}, \mathrm{NO}_{2}{ }^{-}$, and $\mathrm{NH}_{4}{ }^{+}$to $\mathrm{N}_{2} \mathrm{O}$ under high salt and anaerobic conditions (Fig. 1).

\section{General genome features of Halomicrobium sp. ZPS1}

After filtering the raw data, we obtained clean data and 108,469 reads with $1,028,063,020$ nucleotides, and the mean read length was $9477 \mathrm{bp}$. Then, the raw data were assembled through SMRT Link v5.0.1, generating one contig. We obtained a complete genome sequence of Halomicrobium sp. ZPS1, which contained a circular chromosome of 3,094,203 bp in length and a $\mathrm{G}+\mathrm{C}$ content of $65.64 \%$. Meanwhile, 6 rRNA operons, 76 tRNA genes, 10 genomics islands, 1 CRISPR system, 2 prophages, and 3191 protein-coding genes (CDSs) were identified (Fig. 2 and Table 1). The results of genome annotation showed that 1426 CDSs could be annotated by the KEGG database, 2212 CDSs could be annotated by the COG database, and 1967 CDSs could be annotated by the GO database.

\section{Functional annotation of Halomicrobium sp. ZPS1}

To identify the gene functions of Halomicrobium sp. ZPS1, the genome was functionally annotated with five databases. The GO classification results revealed that the

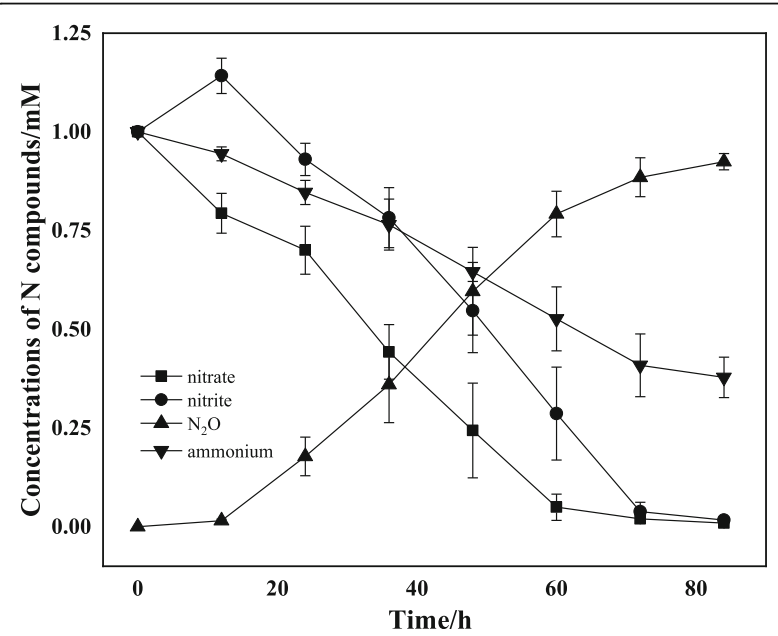

Fig. 1 Degradation of nitrate, nitrite, and ammonium by Halomicrobium sp. ZPS1 at $\mathrm{NaCl}$ concentration of $18 \%$ number of genes encoding biological processes is more than those encoding molecular functions and cellular components (Additional file 1: Fig. s1). Based on the analysis of COG, we can classify the 2212 proteinencoding genes into 24 categories. The result indicates that the number of matched protein-coding gene numbers of $\mathrm{R}$ (general function prediction only) is much higher than those of other categories, including J (translation, ribosomal structure, and biogenesis), E (amino acid transport and metabolism), $\mathrm{K}$ (transcription), and $\mathrm{H}$ (coenzyme transport and metabolism) (Fig. 3).

The KEGG pathway results show that 813 proteincoding genes are associated with 133 KEGG pathways. Among the 555 protein-coding genes, 7 genes are related to cellular processes, 79 genes are related to environmental information processing, 171 genes are related to genetic information processing, 1 gene is related to human disease, 554 genes are related to metabolism, and 1 gene is related to organismal systems. Most genes are associated with metabolism, and the number of genes related to amino acid metabolism (137), carbohydrate metabolism (110), metabolism with cofactors and vitamins (93), nucleotide metabolism (78), and energy metabolism (58) is more than those of other pathwayrelated genes (Additional file 1: Fig. s2).

According to the results of BLASTP searches in NR databases, 1161 genes were annotated, and the two $16 \mathrm{~S}$ rRNA sequences of Halomicrobium sp. ZPS1 showed the highest identity with Halomicrobium mukohataei (100\%) (Additional file 1: Fig. s3).

\section{The mechanism of salt tolerance}

In addition, through COG annotation of the complete genome sequence of Halomicrobium sp. ZPS1, 13 genes related to $\mathrm{Na}^{+} / \mathrm{K}^{+}$transportation were also found, which means that Halomicrobium sp. ZPS1 could exist in saline or hypersaline environments through the enrichment of potassium ions and discharge of sodium ions, also called the "salt-in" strategy (Table 2). Halomicrobium sp. ZPS1 balanced the osmotic pressure of the medium by accumulating intracellular $\mathrm{K}^{+}$to a high concentration through a $\mathrm{K}^{+}$transport system and pumping $\mathrm{Na}^{+}$through an electrogenic $\mathrm{Na}^{+} / \mathrm{H}^{+}$antiporter (Mnh). Moreover, the $\mathrm{Na}^{+} / \mathrm{H}^{+}$ antiporter also plays an essential role in the homeostasis of intracellular pH (Aharon 1999).

\section{Genes involved in nitrogen metabolism}

By comparing the amino acid sequence of Halomicrobium sp. ZPS1 with the COG database, we obtained a total of 2213 genes encoding different functional enzymes, and at least 10 reductase genes involved in nitrogen metabolism were obtained, including nitrate reductase-, nitrite reductase-, nitric oxide reductase-, nitrate/nitrite transporter-, nitrous oxide reductase-, glutamate dehydrogenase-, glutamate 


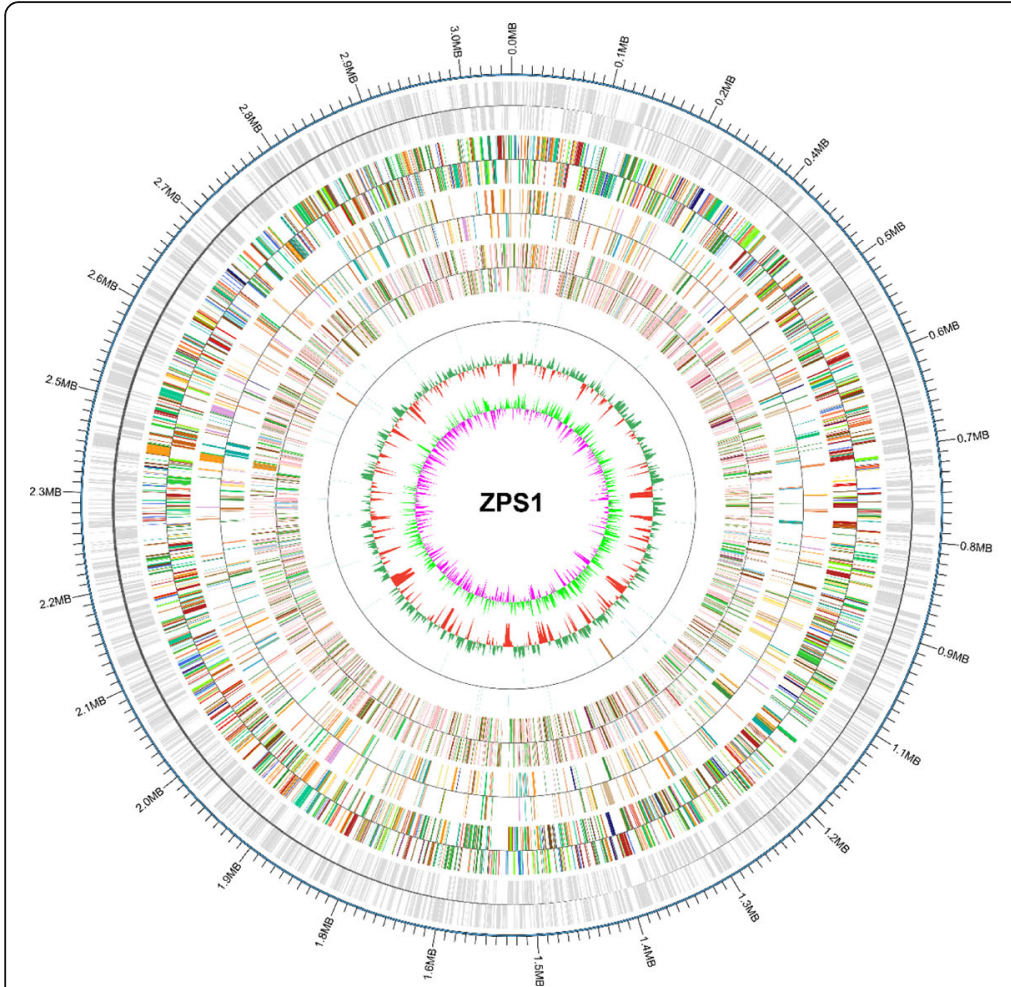

\section{COG Functional categories}

\begin{tabular}{l} 
INFORMATION STORAGE AND PROCESSING \\
J: Translation, ribosomal structure and biogenesis \\
K: Transcription \\
L: Replication, recombination and repair \\
B: Chromatin structure and dynamics \\
CELLULAR PROCESSES AND SIGNALING \\
$\square$ D: Cell cycle control, cell division, chromosome partitioning \\
V: Defense mechanisms \\
T: Signal transduction mechanisms \\
M: Cell wall/membrane/envelope biogenesis \\
N: Cell motility \\
Z: Cytoskeleton \\
W: Extracellular structures \\
U: Intracellular trafficking, secretion, and vesicular transport \\
\hline O: Posttranslational modification, protein turnover, chaperones \\
X: Mobilome: prophages, transposons \\
METABOLISM \\
$\square$ C: Energy production and conversion \\
$\square$ G: Carbohydrate transport and metabolism \\
E: Amino acid transport and metabolism \\
F: Nucleotide transport and metabolism \\
H: Coenzyme transport and metabolism \\
I: Lipid transport and metabolism \\
P: Inorganic ion transport and metabolism \\
Q: Secondary metabolites biosynthesis, transport and catabolism \\
POORLY CHARACTERIZED \\
R: General function prediction only \\
S: Function unknown
\end{tabular}

Fig. 2 Genome map of Halomicrobium sp. ZPS1. From the outer cycle to the inner cycle, circle 1 indicates the total base pairs and the position coordinates of the genomic sequence; circle 2 shows the coding genes; circles 3, 4, and 5 represent the gene functional annotation results colored according to COG, KEGG, and GO, respectively; circle 6 shows the ncRNAs; circle 7 indicates the genomic GC content; and circle 8 illustrates the genomic GC skew value distribution

Table 1 Overview of genomic features of Halomicrobium sp.ZPS1

\begin{tabular}{ll}
\hline Attributes & Characteristics \\
\hline Genome size(Mb) & 3.09 \\
GC content(\%) & 65.64 \\
CDS & 3191 \\
tRNA genes & 76 \\
rRNA genes & 6 \\
snRNA genes & 0 \\
Secondary metabolite BGCS & 3 \\
Genes assigned to COG & 2212 \\
Genes assigned to KEGG & 1426 \\
Genes assigned to GO & 1967 \\
Genes assigned to CAZy & 47 \\
Genes assigned to NR & 1165 \\
GenBank accession number & CP045142 \\
\hline
\end{tabular}

synthase-, and ammonia channel protein-encoding genes (Table 2). However, through the comparison with other denitrifiers, we found that the gene encoding the nitrous oxide reductase in Halomicrobium sp. ZPS1 was nosL, which might be a remnant of a complete operon, and this gene did not transcribe a protein with synthesize nitrous oxide reductase (Lycus et al. 2017). We consider that Halomicrobium sp. ZPS1 could perform a truncated denitrification pathway, reducing nitrate or nitrite to nitrous oxide.

Based on the analysis of the KEGG database, the nitrogen metabolism pathways are performed (Fig. 4), and Halomicrobium sp. ZPS1 could reduce nitrate or nitrite to nitrous oxide through truncated denitrification under salty environments. Nitrate is first reduced to nitrite by nitrate reductase, then to nitric oxide by nitrite reductase, and finally to nitrous oxide by nitric oxide reductase. In the assimilatory nitrate reduction pathway, nitrite existing in salted vegetables could be transported into the cells through nitrate/nitrite transporters and further reduced to $\mathrm{NH}_{4}^{+}$by assimilatory nitrite reductase.

\section{Discussion}

Haloarchaea exist in saline or hypersaline environments where other microorganisms hardly exist, and they could 


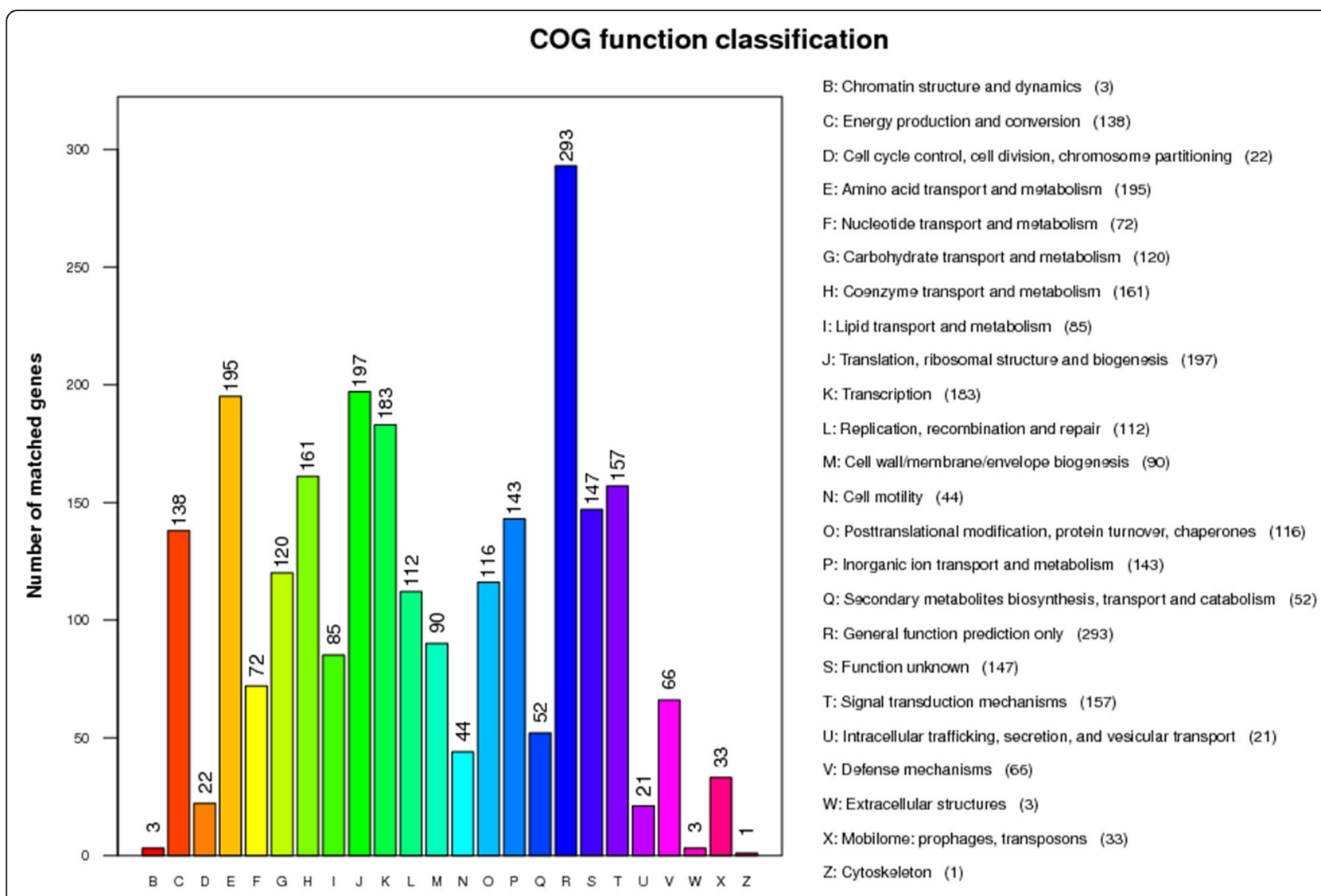

Function class

Fig. 3 COG categories of coding proteins, $x$-axis indicates the function classes and $y$-axis indicates the number of the predicted proteins in Halomicrobium sp. ZPS1

maintain normal growth and metabolism in these environments. It has been found that the intracellular ionic composition of haloarchaea is different from the outer extracellular environment; the environment contains $\mathrm{NaCl}$ as the main salt, while the cytoplasm contains more $\mathrm{KCl}$ than outside environment (Aharon 1999). This could be regarded as a salt-in strategy, which is expected to provide the ability to survive in high salt environments. In this study, we annotated genes related to the $\mathrm{K}^{+}$transport system and $\mathrm{Na}^{+} / \mathrm{H}^{+}$antiporter (Mnh), which indicates that Halomicrobium sp. ZPS1 grows in high salinity environments through a "salt-in" strategy, and $\mathrm{K}^{+}$existing in the medium is critical for the growth and metabolism of Halomicrobium sp. ZPS1.

Under the condition of $18 \%$ salt concentration, the growth and metabolism of Halomicrobium sp. ZPS1, the concentration of $\mathrm{NO}_{3}{ }^{-}, \mathrm{NO}_{2}{ }^{-}$, and $\mathrm{NH}_{4}{ }^{+}$could be decreased, and $\mathrm{N}_{2} \mathrm{O}$ was simultaneously produced; however, no $\mathrm{N}_{2}$ was produced. Based on these physiological characteristics, we can speculate that the degradation of nitrate and nitrite is attributed to truncated denitrification.
Denitrification in microorganisms is a dissimilatory process in which nitrate or nitrite is reduced to nitrogenous gas (Wei et al. 2015); this process includes four steps, $\mathrm{NO}_{3}{ }^{-} \rightarrow \mathrm{NO}_{2}{ }^{-} \rightarrow \mathrm{NO} \rightarrow \mathrm{N}_{2} \mathrm{O} \rightarrow \mathrm{N}_{2} \quad$ (Verstraete and Focht 1977), and these four steps are catalyzed by four different kinds of enzymes, nitrate reductase (Nar), nitrite reductase (Nir), nitric oxide reductase (Nor), and nitrous oxide reductase (Nos) (Philippot 2002). Through the annotation of the complete genome of Halomicrobium sp. ZPS1, the nar, nir, and nor were found but nos was not, which means that ZPS1 could perform a truncated denitrification pathway, and nitrate and nitrite could be reduced to nitrous oxide and released to the atmosphere, making salted vegetables free of nitrate or nitrite residues.

Moreover, according to the previous physiological characteristics, we can also speculate that the degradation of ammonium is achieved by ammonium assimilation. Through the annotation of the complete genome of Halomicrobium sp. ZPS1, genes related to ammonium assimilation and ammonia transportation, including glutamine synthetase-, glutamate dehydrogenase-, and 
Table 2 The denitrification related genes in COG database

\begin{tabular}{|c|c|c|c|c|c|c|}
\hline & $\begin{array}{l}\text { Identity } \\
(\%)\end{array}$ & E value & $\begin{array}{l}\text { COG gene } \\
\text { ID }\end{array}$ & Functional description & $\begin{array}{l}\text { Functional } \\
\text { class }\end{array}$ & Class description \\
\hline $\begin{array}{l}\text { ZPS1 } \\
\text { GM001562 }\end{array}$ & 100 & $0.00 \mathrm{E}+00$ & $\begin{array}{l}\text { YP } \\
003176769\end{array}$ & Nitrate reductase gamma subunit & $\mathrm{CP}$ & $\begin{array}{l}\text { Energy production and conversion } \\
\text { Inorganic ion transport and } \\
\text { metabolism }\end{array}$ \\
\hline $\begin{array}{l}\text { ZPS1 } \\
\text { GM002221 }\end{array}$ & 47.9 & 1.40E-96 & $\begin{array}{l}\text { YP } \\
008376898\end{array}$ & Nitrate/nitrite transporter NarK & $P$ & $\begin{array}{l}\text { Inorganic ion transport and } \\
\text { metabolism }\end{array}$ \\
\hline $\begin{array}{l}\text { ZPS1 } \\
\text { GM003113 }\end{array}$ & 100 & $\begin{array}{l}1.00 E \\
-223\end{array}$ & $\begin{array}{l}\text { YP } \\
003178284\end{array}$ & Nitrate reductase beta subunit & $\mathrm{CP}$ & $\begin{array}{l}\text { Energy production and conversion } \\
\text { Inorganic ion transport and } \\
\text { metabolism }\end{array}$ \\
\hline $\begin{array}{l}\text { ZPS1 } \\
\text { GM003113 }\end{array}$ & 100 & $\begin{array}{l}1.00 E \\
-223\end{array}$ & $\begin{array}{l}\text { YP } \\
003178284\end{array}$ & Nitrate reductase beta subunit & $\mathrm{CP}$ & $\begin{array}{l}\text { Energy production and conversion } \\
\text { Inorganic ion transport and } \\
\text { metabolism }\end{array}$ \\
\hline $\begin{array}{l}\text { ZPS1 } \\
\text { GM003114 }\end{array}$ & 100 & $0.00 \mathrm{E}+00$ & $\begin{array}{l}\text { YP } \\
003178285\end{array}$ & Nitrate reductase alpha subunit & $\mathrm{CP}$ & $\begin{array}{l}\text { Energy production and conversion } \\
\text { Inorganic ion transport and } \\
\text { metabolism }\end{array}$ \\
\hline $\begin{array}{l}\text { ZPS1 } \\
\text { GM000464 }\end{array}$ & 45.9 & $5.20 \mathrm{E}-07$ & $\begin{array}{l}\text { YP } \\
007284710\end{array}$ & $\begin{array}{l}\text { Ferredoxin subunit of nitrite reductase or a ring- } \\
\text { hydroxylating dioxygenase }\end{array}$ & $P Q$ & $\begin{array}{l}\text { Inorganic ion transport and } \\
\text { metabolism } \\
\text { Secondary metabolites biosynthesis, } \\
\text { transport and catabolism }\end{array}$ \\
\hline $\begin{array}{l}\text { ZPS1 } \\
\text { GM000538 }\end{array}$ & 100 & $9.60 \mathrm{E}-77$ & $\begin{array}{l}\text { YP } \\
003178896\end{array}$ & $\begin{array}{l}\text { Ferredoxin subunit of nitrite reductase or a ring- } \\
\text { hydroxylating dioxygenase }\end{array}$ & $\mathrm{PQ}$ & $\begin{array}{l}\text { Inorganic ion transport and } \\
\text { metabolism } \\
\text { Secondary metabolites biosynthesis, } \\
\text { transport, and catabolism }\end{array}$ \\
\hline $\begin{array}{l}\text { ZPS1 } \\
\text { GM001048 }\end{array}$ & 100 & 7.90E-97 & $\begin{array}{l}\text { YP } \\
003176228\end{array}$ & $\begin{array}{l}\text { Ferredoxin subunit of nitrite reductase or a ring- } \\
\text { hydroxylating dioxygenase }\end{array}$ & $P Q$ & $\begin{array}{l}\text { Inorganic ion transport and } \\
\text { metabolism } \\
\text { Secondary metabolites biosynthesis, } \\
\text { transport, and catabolism }\end{array}$ \\
\hline $\begin{array}{l}\text { ZPS1 } \\
\text { GM002618 }\end{array}$ & 100 & $0.00 \mathrm{E}+00$ & $\begin{array}{l}\text { YP } \\
003177800\end{array}$ & Nitric oxide reductase large subunit & $P$ & $\begin{array}{l}\text { Inorganic ion transport and } \\
\text { metabolism }\end{array}$ \\
\hline $\begin{array}{l}\text { ZPS1 } \\
\text { GM001012 }\end{array}$ & 100 & $\begin{array}{l}6.60 \mathrm{E} \\
-102\end{array}$ & $\begin{array}{l}\text { YP } \\
003176191\end{array}$ & Nitrous oxide reductase accessory protein NosL & $P$ & $\begin{array}{l}\text { Inorganic ion transport and } \\
\text { metabolism }\end{array}$ \\
\hline $\begin{array}{l}\text { ZPS1 } \\
\text { GM001342 }\end{array}$ & 100 & $\begin{array}{l}2.10 \mathrm{E} \\
-261\end{array}$ & $\begin{array}{l}\text { YP } \\
003176547\end{array}$ & Glutamine synthetase & $\mathrm{E}$ & Amino acid transport and metabolism \\
\hline $\begin{array}{l}\text { ZPS1 } \\
\text { GM000568 }\end{array}$ & 100 & $\begin{array}{l}3.10 \mathrm{E} \\
-235\end{array}$ & $\begin{array}{l}\text { YP } \\
003178926\end{array}$ & Glutamate dehydrogenase/leucine dehydrogenase & $\mathrm{E}$ & Amino acid transport and metabolism \\
\hline $\begin{array}{l}\text { ZPS1 } \\
\text { GM000588 }\end{array}$ & 100 & $\begin{array}{l}6.00 \mathrm{E} \\
-239\end{array}$ & $\begin{array}{l}\text { YP } \\
003178946\end{array}$ & Glutamate dehydrogenase/leucine dehydrogenase & $\mathrm{E}$ & Amino acid transport and metabolism \\
\hline $\begin{array}{l}\text { ZPS1 } \\
\text { GM000589 }\end{array}$ & 100 & $0.00 \mathrm{E}+00$ & $\begin{array}{l}\text { YP } \\
003178947\end{array}$ & Glutamate synthase domain 3 & $\mathrm{E}$ & Amino acid transport and metabolism \\
\hline $\begin{array}{l}\text { ZPS1 } \\
\text { GM001552 }\end{array}$ & 100 & $\begin{array}{l}1.50 \mathrm{E} \\
-253\end{array}$ & $\begin{array}{l}\text { YP } \\
003176759\end{array}$ & Ammonia channel protein AmtB & $P$ & $\begin{array}{l}\text { Inorganic ion transport and } \\
\text { metabolism }\end{array}$ \\
\hline $\begin{array}{l}\text { ZPS1 } \\
\text { GM000021 }\end{array}$ & 100 & $\begin{array}{l}2.50 \mathrm{E} \\
-251\end{array}$ & $\begin{array}{l}\text { YP } \\
003178383\end{array}$ & $\mathrm{Na}^{+}$-dependent transporter, SNF family & $\mathrm{R}$ & General function prediction only \\
\hline $\begin{array}{l}\text { ZPS1 } \\
\text { GM000159 }\end{array}$ & 99.7 & $\begin{array}{l}7.80 \mathrm{E} \\
-187\end{array}$ & $\begin{array}{l}\text { YP } \\
003178520\end{array}$ & ABC-type $\mathrm{Na}^{+}$efflux pump, permease component & $\mathrm{CP}$ & $\begin{array}{l}\text { Energy production and conversion } \\
\text { Inorganic ion transport and } \\
\text { metabolism }\end{array}$ \\
\hline $\begin{array}{l}\text { ZPS1 } \\
\text { GM000311 }\end{array}$ & 100 & $\begin{array}{l}1.30 \mathrm{E} \\
-180\end{array}$ & $\begin{array}{l}\text { YP } \\
003178669\end{array}$ & Multisubunit $\mathrm{Na}^{+} / \mathrm{H}^{+}$antiporter, MnhE subunit & $P$ & $\begin{array}{l}\text { Inorganic ion transport and } \\
\text { metabolism }\end{array}$ \\
\hline $\begin{array}{l}\text { ZPS1 } \\
\text { GM000312 }\end{array}$ & 100 & $1.30 \mathrm{E}-42$ & $\begin{array}{l}\text { YP } \\
003178670\end{array}$ & Multisubunit $\mathrm{Na}^{+} / \mathrm{H}^{+}$antiporter, MnhF subunit & $P$ & $\begin{array}{l}\text { Inorganic ion transport and } \\
\text { metabolism }\end{array}$ \\
\hline $\begin{array}{l}\text { ZPS1 } \\
\text { GM000313 }\end{array}$ & 100 & $6.40 \mathrm{E}-55$ & $\begin{array}{l}\text { YP } \\
003178671\end{array}$ & Multisubunit $\mathrm{Na}^{+} / \mathrm{H}^{+}$antiporter, MnhG subunit & $P$ & $\begin{array}{l}\text { Inorganic ion transport and } \\
\text { metabolism }\end{array}$ \\
\hline $\begin{array}{l}\text { ZPS1 } \\
\text { GM000315 }\end{array}$ & 100 & $7.20 \mathrm{E}-81$ & $\begin{array}{l}\text { YP } \\
003178673\end{array}$ & Multisubunit $\mathrm{Na}^{+} / \mathrm{H}^{+}$antiporter, $\mathrm{MnhB}$ subunit & P & $\begin{array}{l}\text { Inorganic ion transport and } \\
\text { metabolism }\end{array}$ \\
\hline $\begin{array}{l}\text { ZPS1 } \\
\text { GM000316 }\end{array}$ & 99.2 & $3.50 \mathrm{E}-59$ & $\begin{array}{l}\text { YP } \\
003178674\end{array}$ & Multisubunit $\mathrm{Na}^{+} / \mathrm{H}^{+}$antiporter, MnhC subunit & $P$ & $\begin{array}{l}\text { Inorganic ion transport and } \\
\text { metabolism }\end{array}$ \\
\hline
\end{tabular}


Table 2 The denitrification related genes in COG database (Continued)

\begin{tabular}{|c|c|c|c|c|c|c|}
\hline & $\begin{array}{l}\text { Identity } \\
(\%)\end{array}$ & Evalue & $\begin{array}{l}\text { COG gene } \\
\text { ID }\end{array}$ & Functional description & $\begin{array}{l}\text { Functional } \\
\text { class }\end{array}$ & Class description \\
\hline $\begin{array}{l}\text { ZPS1 } \\
\text { GM000318 }\end{array}$ & 100 & $0.00 \mathrm{E}+00$ & $\begin{array}{l}\text { YP } \\
003178676\end{array}$ & $\begin{array}{l}\text { Formate hydrogenlyase subunit 3/Multisubunit } \\
\mathrm{Na}^{+} / \mathrm{H}^{+} \text {antiporter, MnhD subunit }\end{array}$ & $\mathrm{CP}$ & $\begin{array}{l}\text { Energy production and conversion } \\
\text { Inorganic ion transport and } \\
\text { metabolism }\end{array}$ \\
\hline $\begin{array}{l}\text { ZPS1 } \\
\text { GM000779 }\end{array}$ & 100 & $\begin{array}{l}1.10 \mathrm{E} \\
-262\end{array}$ & $\begin{array}{l}\text { YP } \\
003175955\end{array}$ & $\mathrm{Na}^{+}$-dependent transporter, SNF family & $\mathrm{R}$ & General function prediction only \\
\hline $\begin{array}{l}\text { ZPS1 } \\
\text { GM001320 }\end{array}$ & 100 & $\begin{array}{l}4.10 \mathrm{E} \\
-279\end{array}$ & $\begin{array}{l}\text { YP } \\
003176524\end{array}$ & $\mathrm{Na}^{+}$-driven multidrug efflux pump & V & Defense mechanisms \\
\hline $\begin{array}{l}\text { ZPS1 } \\
\text { GM003089 }\end{array}$ & 100 & $\begin{array}{l}2.20 \mathrm{E} \\
-158\end{array}$ & $\begin{array}{l}\text { YP } \\
003178260\end{array}$ & Predicted Na+-dependent transporter & $\mathrm{R}$ & General function prediction only \\
\hline $\begin{array}{l}\text { ZPS1 } \\
\text { GM001370 }\end{array}$ & 100 & $0.00 \mathrm{E}+00$ & $\begin{array}{l}\text { YP } \\
003176577\end{array}$ & Trk K+ transport system, NAD-binding component & $P$ & $\begin{array}{l}\text { Inorganic ion transport and } \\
\text { metabolism }\end{array}$ \\
\hline $\begin{array}{l}\text { ZPS1 } \\
\text { GM002514 }\end{array}$ & 99.8 & $\begin{array}{l}1.10 \mathrm{E} \\
-293\end{array}$ & $\begin{array}{l}\text { YP } \\
003177697\end{array}$ & $\begin{array}{l}\text { Trk-type } \mathrm{K}^{+} \text {transport system, membrane } \\
\text { component }\end{array}$ & $P$ & $\begin{array}{l}\text { Inorganic ion transport and } \\
\text { metabolism }\end{array}$ \\
\hline
\end{tabular}

ammonia channel protein-encoding genes, were also found in the complete genome. This means that ammonia could be transported into the cytoplasm from the periplasm through the ammonia channel protein $(\mathrm{amtB})$ and further assimilated to L-glutamate from L-glutamine (Fig. 4), which could maintain the normal growth of Halomicrobium sp. ZPS1. This means that $\mathrm{NH}_{4}{ }^{+}$produced from nitrite or that existed in the vegetables could be involved in carbon metabolism by the glutamine synthetase/glutamate synthase pathway, and maintain the growth of Halomicrobium sp. ZPS1 without additional carbon and nitrogen sources, and it makes it possible to eliminate nitrate, nitrite, and ammonia simultaneously.

Oxalic, malate, malonic, erythorbic acid, glutamic acid, and other organic acids are present in radish (Gutiérrez and Perez 2004). Genes involved in the reductive tricarboxylic acid (TCA) cycle were obtained through the KEGG database except 2-oxoglutarate dehydrogenaseencoding genes, which means that malate could act as an electron donor and carbon source for cells, allowing the cells to maintain growth. The energy for Halomicrobium sp. ZPS1 to synthesize fumarate and succinate

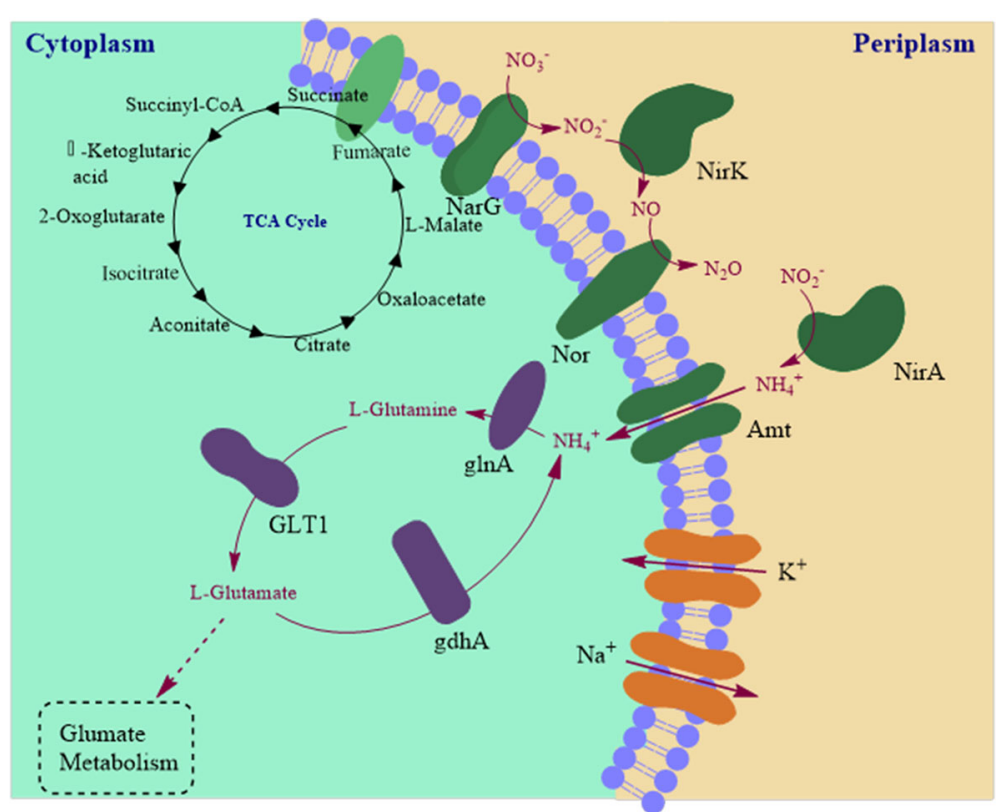

Fig. 4 Genome-based nitrogen metabolism pathways of Halomicrobium sp. ZPS1. Nitrate and nitrite could be reduced to nitrous oxide through a truncated denitrification pathway. Ammonium existing in the vegetables or formed by nitrite assimilatory could be transported into the cytochrome and transformed to L-glutamate, formed L-glutamate, which could participate in glutamate metabolism. Halomicrobium sp. ZPS1 could perform a reductive TCA cycle, and electrons generated from succinate to fumarate could be transferred to denitrification pathways. NarG, nitrite reductase; Nirk, cooper-containing nitrite reductase; Nor, nitric oxide reductase; NirA, ferredoxin-nitrite reductase; Amt, ammonia channel protein; glnA, glutamine synthetase; GLT1, glutamate synthase; gdhA, glutamate dehydrogenase 
comes from metabolizing the malate in salted vegetables, and the transformation of fumarate and succinate provides electrons for the truncated denitrification pathway (Fig. 4). Thus, nitrate, nitrite, and ammonium could act as nitrogen resources, and organic acids present in salted vegetables act as carbon resources to provide electrons and energy for cells; therefore, the cells are able to maintain respiration and growth and remove nitrogen contaminants without additional carbon and nitrogen resources.

The safety of haloarchaea applications for food has not been confirmed so far, mainly because it is impossible to simulate the high salt environment in which that haloarchaea inhabit in mice. Edible sea salt and mineral salt contain a large amount of haloarchaea; however, cells could rupture and die due to the osmotic pressure of the normal human body; therefore, it is difficult to find haloarchaea in the human body. If the safety of haloarchaea can be confirmed, they can provide a feasible solution for the complete removal of nitrogen contaminants from high-salt vegetables. Halomicrobium sp. ZPS1 could be a potential resource for the elimination of nitrite and nitrate in salted food.

\section{Conclusion}

This study reports the complete genome sequence of Halomicrobium sp. ZPS1 isolated from a salt mine in China. The phylogeny analysis indicates that ZPS1 is closely related to Halomicrobium mukohataei. By assembling and annotating the complete genome, we considered that ZPS1 could grow in a high salinity environment by using a "salt-in" strategy and ammonium assimilation and reduce nitrate into $\mathrm{N}_{2} \mathrm{O}$ via a truncated denitrification pathway. The results indicated that Halomicrobium sp. ZPS1 might be a candidate strain for the simultaneous removal of nitrate, nitrite, and ammonia in the process of salted vegetable production, as well as in other high salinity environments.

\section{Supplementary information}

Supplementary information accompanies this paper at https://doi.org/10. 1186/s13213-020-01575-8.

Additional file 1: Figure S1. GO classification of genome function in Halomicrobium sp. ZPS1. Figure S2. KEGG categories of coding proteins in Halomicrobium sp. ZPS1. Figure S3. Phylogenetic tree based on 165 rRNA sequences of Halomicrobium sp. ZPS1. Bootstrap values greater than $50 \%$ are shown. Scale bar represents substitutions per nucleotide.

\section{Acknowledgements}

The authors thank the National Natural Science Foundation of China and the Natural Science Foundation of Jiangsu Province of China for the scholarships granted to Feng Gao for her help and instruction of strain isolation and to Dong Han for the instruction of complete genome analysis, respectively.

\section{Competing interests}

The authors declare that they have no competing interests.

\section{Research involving human participants and/or animals}

N/A

Informed consent

$\mathrm{N} / \mathrm{A}$

\section{Authors' contributions}

All the authors designed this study. $\mathrm{XyH}$ performed the experiment and drafted the manuscript. $\mathrm{XyH}, \mathrm{ClZ}, \mathrm{KI}, \mathrm{KS}$ and $\mathrm{LZ}$ analyzed and performed the data. $\mathrm{ZzH}, \mathrm{YW}$ and $\mathrm{QX}$ contributed reagents/materials/analysis tools. The author(s) read and approved the final manuscript.

\section{Funding}

This work was financially supported by the National Natural Science Foundation of China (31600069, 41503068, 31770543), the Natural Science Foundation of Jiangsu Province of China (BK20150496, BK20150497), and the Priority Academic Program Development of Jiangsu Higher Education Institutions.

\section{Author details}

${ }^{1}$ School of Agricultural Equipment Engineering, Jiangsu University, Zhenjiang, China. ${ }^{2}$ School of Food and Biological Engineering, Jiangsu University, Zhenjiang, China. ${ }^{3}$ Department of Applied Biological Chemistry, Graduate School of Agricultural and Life Sciences, The University of Tokyo, Tokyo, Japan.

Received: 16 December 2019 Accepted: 29 January 2020

Published online: 15 May 2020

\section{References}

Aharon O (1999) Bioenergetic aspects of halophilism. Microbiol Mol Biol Rev 63: $334-348$

Aharon O (2002) Diversity of halophilic microorganisms: environments, phylogeny, physiology, and applications. J Ind Microbiol Biotechnol 28:56-63

Ardui S, Ameur A, Vermeesch JR, Hestand MS (2018) Single molecule real-time (SMRT) sequencing comes of age: applications and utilities for medical diagnostics. Nucleic Acids Res 46:2159-2168

Ashburner M et al (2000) Gene ontology: tool for the unification of biology. Nat Genet 25:25

Benson G (1999) Tandem repeats finder: a program to analyze DNA sequences. Nucleic Acids Res 27:573-580

Besemer J, Lomsadze A, Borodovsky M (2001) GeneMarkS: a self-training method for prediction of gene starts in microbial genomes. Implications for finding sequence motifs in regulatory regions. Nucleic Acids Res 29:2607-2618

Cantarel BL, Coutinho PM, Rancurel C, Bernard T, Lombard V, Henrissat B (2008) The Carbohydrate-Active EnZymes database (CAZy): an expert resource for glycogenomics. Nucleic Acids Res 37:D233-D238

Carr FJ, Chill D, Maida N (2002) The lactic acid bacteria: a literature survey. Crit Rev Microbiol 28:281-370

Cheung J, Danna KJ, O'Connor EM, Price LB, Shand RF (1997) Isolation, sequence, and expression of the gene encoding halocin $\mathrm{H} 4$, a bacteriocin from the halophilic archaeon Haloferax mediterranei R4. J Bacteriol 179:548-551

Ding Z, Johanningsmeier SD, Price R, Reynolds R, Truong V-D, Payton SC, Breidt F (2018) Evaluation of nitrate and nitrite contents in pickled fruit and vegetable products. Food Control 90:304-311

Galperin MY, Makarova KS, Wolf YI, Koonin EV (2014) Expanded microbial genome coverage and improved protein family annotation in the COG database. Nucleic Acids Res 43:D261-D269

Gardner PP et al (2008) Rfam: updates to the RNA families database. Nucleic Acids Res 37:D136-D140

Grissa I, Vergnaud G, Pourcel C (2007) CRISPRFinder: a web tool to identify clustered regularly interspaced short palindromic repeats. Nucleic Acids Res 35:W52-W57

Gutiérrez RMP, Perez RL (2004) Raphanus sativus (Radish): their chemistry and biology. Sci World J 4:811-837

Hebert PD et al (2018) A Sequel to Sanger: amplicon sequencing that scales. BMC Genomics 19:219

Henriet O, Fourmentin J, Delincé B, Mahillon J (2014) Exploring the diversity of extremely halophilic archaea in food-grade salts. Int J Food Microbiol 191:36-44

Hsiao W. Wan I, Jones SJ, Brinkman FS (2003) IslandPath: aiding detection of genomic islands in prokaryotes. Bioinformatics 19:418-420 
Jetten MS, Wagner M, Fuerst J, van Loosdrecht M, Kuenen G, Strous M (2001) Microbiology and application of the anaerobic ammonium oxidation ('anammox') process. Curr Opin Biotechnol 12:283-288

Kanehisa M, Goto S, Kawashima S, Okuno Y, Hattori M (2004) The KEGG resource for deciphering the genome. Nucleic Acids Res 32:D277-D280

Kanehisa M et al (2006) From genomics to chemical genomics: new developments in KEGG. Nucleic Acids Res 34:D354-D357

Lagesen K, Hallin P, Rødland EA, Stærfeldt H-H, Rognes T, Ussery DW (2007) RNAmmer: consistent and rapid annotation of ribosomal RNA genes. Nucleic Acids Res 35:3100-3108

Li W, Jaroszewski L, Godzik A (2002) Tolerating some redundancy significantly speeds up clustering of large protein databases. Bioinformatics 18:77-82

Lowe TM, Eddy SR (1997) tRNAscan-SE: a program for improved detection of transfer RNA genes in genomic sequence. Nucleic Acids Res 25:955-964

Lycus P, Lovise BK, Bergaust L, Peele SJ, Reier BL, Frostegård A (2017) Phenotypic and genotypic richness of denitrifiers revealed by a novel isolation strategy. ISME J:11

Mardis ER (2017) DNA sequencing technologies: 2006-2016. Nat Protoc 12:213

Medema MH et al (2011) antiSMASH: rapid identification, annotation and analysis of secondary metabolite biosynthesis gene clusters in bacterial and fungal genome sequences. Nucleic Acids Res 39:W339-W346

Ngo T, Phan A, Yam C, Lenhoff H (1982) Interference in determination of ammonia with the hypochlorite-alkaline phenol. Method Berthelot Analyt Chem 54:46-49

Oh C-K, Oh M-C, Kim S-H (2004) The depletion of sodium nitrite by lactic acid bacteria isolated from kimchi. J Med Food 7:38-44

Ozdestan O, Uren A (2010) Development of a cost-effective method for nitrate and nitrite determination in leafy plants and nitrate and nitrite contents of some green leafy vegetables grown in the Aegean region of Turkey. J Agric Food Chem 58:5235-5240

Pfeifer F (2015) Haloarchaea and the formation of gas vesicles. Life 5:385-402

Philippot L (2002) Denitrifying genes in bacterial and archaeal genomes. Biochim Biophys Acta Gene Struct Expr 1577:355-376

Reiner J et al (2018) Cytogenomic identification and long-read single molecule real-time (SMRT) sequencing of a Bardet-Biedl Syndrome 9 (BBS9) deletion. NPJ Genom Med 3:3

Torregrosa-Crespo J, Pire C, Martínez-Espinosa RM, Bergaust L (2019) Denitrifying haloarchaea within the genus Haloferax display divergent respiratory phenotypes, with implications for their release of nitrogenous gases. Environ Microbiol 21:427-436

Verstraete W, Focht D (1977) Biochemical ecology of nitrification and denitrification. In: Advances in microbial ecology. Springer, pp 135-214

Wei $W$ et al (2015) Higher diversity and abundance of denitrifying microorganisms in environments than considered previously. ISME J 9:1954

Yan P-M, Xue W-T, Tan S-S, Zhang H, Chang X-H (2008) Effect of inoculating lactic acid bacteria starter cultures on the nitrite concentration of fermenting Chinese paocai. Food Control 19:50-55

Yoshimatsu K, Sakurai T, Fujiwara T (2000) Purification and characterization of dissimilatory nitrate reductase from a denitrifying halophilic archaeon, Haloarcula marismortui. FEBS Lett 470:216-220

Yusof AM, Keat LK, Ibrahim Z, Majid ZA, Nizam NA (2010) Kinetic and equilibrium studies of the removal of ammonium ions from aqueous solution by rice husk ash-synthesized zeolite $Y$ and powdered and granulated forms of mordenite. J Hazard Mater 174:380-385

Zhong W, Hu C, Wang M (2002) Nitrate and nitrite in vegetables from north China: content and intake. Food Addit Contam 19:1125-1129

Zhou Y, Liang Y, Lynch KH, Dennis JJ, Wishart DS (2011) PHAST: a fast phage search tool. Nucleic Acids Res 39:W347-W352

\section{Publisher's Note}

Springer Nature remains neutral with regard to jurisdictional claims in published maps and institutional affiliations.

Ready to submit your research? Choose BMC and benefit from:

- fast, convenient online submission

- thorough peer review by experienced researchers in your field

- rapid publication on acceptance

- support for research data, including large and complex data types

- gold Open Access which fosters wider collaboration and increased citations

- maximum visibility for your research: over $100 \mathrm{M}$ website views per year

At BMC, research is always in progress.

Learn more biomedcentral.com/submissions 